\title{
Partitioning of Fe during carbonation of Fe-rich brucite
}

\author{
COLTON VESSEY ${ }^{1}$, SIOBHAN WILSON ${ }^{1}$, MAIJA \\ RAUDSEPP $^{1}$ AND ANNA HARRISON ${ }^{2}$ \\ ${ }^{1}$ University of Alberta \\ ${ }^{2}$ Géosciences Environnement Toulouse (GET) - CNRS \\ Presenting Author: vessey@ualberta.ca
}

Carbon capture, utilization, and storage (CCUS) technologies are becoming increasingly important to stabilize atmospheric $\mathrm{CO}_{2}$ concentrations. ${ }^{1}$ One such technology being utilized in alkaline mining systems is mineral carbonation - removal of $\mathrm{CO}_{2}$ by precipitation of benign calcium $(\mathrm{Ca})$ and magnesium $(\mathrm{Mg})$ carbonate minerals, such as calcite $(\mathrm{CaCO} 3)$ or hydrated magnesium carbonate phases \{e.g., hydromagnesite $\left.\left[\mathrm{Mg}_{5}\left(\mathrm{CO}_{3}\right)_{4}(\mathrm{OH})_{2} \cdot 4 \mathrm{H}_{2} \mathrm{O}\right]\right\} .{ }^{2}$ While carbonation products and rates have been well defined for stoichiometric brucite $\left[\mathrm{Mg}(\mathrm{OH})_{2}\right]$, the presence of incorporated trace metals [i.e., iron (Fe)] can impact carbonation efficiency. Remobilization of $\mathrm{Fe}$ during carbonation of $\mathrm{Fe}(\mathrm{II})$-rich brucite can impact secondary phases formed and, therefore, carbonation rates and capacity. ${ }^{3}$ Here we report preliminary results on $\mathrm{Mg}$ and $\mathrm{Fe}$ partitioning as a function of brucite stoichiometry during carbonation reactions.

Batch carbonation experiments were performed by carbonating synthetic Fe(II)-brucite (5, 20, $40 \mathrm{~mol} \%$ ) in both oxic and anoxic conditions with different background anions at $0.1 \mathrm{M}\left(\mathrm{Cl}^{-}, \mathrm{SO}_{4}{ }^{2-}, \mathrm{H}_{4} \mathrm{SiO}_{4}{ }^{0}\right)$. $\mathrm{Fe}(\mathrm{II})$-brucite suspensions (5 $\mathrm{g}$ in $100 \mathrm{~mL}$ of solution) were carbonated for $24 \mathrm{~h}$ with $10 \% \mathrm{CO}_{2}$ mixed with $90 \% \mathrm{~N}_{2}$, or $10 \% \mathrm{CO}_{2}$ in compressed air for anoxic and oxic systems, respectively. Water samples were collected over time to quantify concentrations of $\mathrm{Mg}, \mathrm{Fe}$, and dissolved inorganic carbon (DIC). Solids were preserved and analyzed by X-ray diffraction (XRD) and X-ray absorption spectroscopy (XAS) to identify the solid reaction products as a function of $\mathrm{Fe}$ content.

Preliminary results from combined trace element and spectroscopic analysis indicate the importance of $\mathrm{Fe}$ cycling during carbonation of brucite. Our results will have implications for predicting the efficiency of carbonation reactions as a function of $\mathrm{Fe}$ content substituted into brucite in both oxic and anoxic conditions.

[1] IPCC (2018) Special Report, Global Warming of $1.5^{\circ} \mathrm{C}$ [2] Wilson et al. (2014) Int. J. Greenh. Gas Control, 25, 121-140. [3] Hamilton et al. (2020) Econ. Geol., 115, 303-323. 